\title{
Removal of Paracetamol from Wastewater by Calcined Gypsum: Adsorption and Kinetics Study
}

Hossam Al-Itawi

Department of Natural Resources and Chemical Engineering, Tafila Technical University, Tafila, 66110 Jordan

\begin{abstract}
It has been established that the presence of paracetamol in wastewaters can cause a potential risk to the environment. This work examined the possibility of using calcined gypsum in removing paracetamol from aqueous solutions. At neutral $\mathrm{pH}$ conditions, calcined gypsum was successful in removing paracetamol via adsorption, from aqueous solutions with a removal efficiency that ranged between 56.8 to $65.3 \%$ of an initial concentration of $600 \mathrm{ppm}$. Increased temperature (from 20 to $50^{\circ} \mathrm{C}$ ) had a minor effect on the removal \% of paracetamol while increasing the initial calcined gypsum dose (from $0.5 \mathrm{gm}$ to $3 \mathrm{gm}$ ) and contact time (up to $15 \mathrm{~min}$ ) increased by the removal \% of paracetamol. Thermodynamically, the adsorption of paracetamol by calcined gypsum process was found to be spontaneous and endothermic, and more likely a physical process, while kinetically; the Pseudo-Second order model was found to be the best fit compared to the Elovich model. The removal process mainly consists of two stages, and it could be deduced from the kinetic behavior of paracetamol adsorption that the recrystallization process can be another rate-limiting step in the process.
\end{abstract}

Keywords: Paracetamol, Calcined Gypsum, Adsorption, Kinetics Study, Pseudo-Second Order.

\section{Introduction}

Paracetamol is one of the most important pollutants in industrial wastewater; although the amounts of paracetamol detected in different locations are usually low, however, the long-term discharge may cause potential risk to the environment (Kong et al, 2006). Paracetamol is a common analgesic and antipyretic drug (Kong et al, 2006), has widespread usage as the raw material of many drugs. Removal micro-pollutants including paracetamol from wastewater was achieved by; physical treatment (Ayyash et al., 2015), biological methods and/adsorption followed by ultrafiltration/microfiltration separation(Ayyash et al., 2015; Karaman et al., 2016), chemical treatment(Kong et al., 2006; Felis and Miksch, 2009), advanced oxidation process (Felis and Miksch, 2009; Ratpukdi, 2014), as well as membrane separation techniques (Ayyash et al., 2015). Several authors have studied the treatment of micro-polluted in wastewater especially paracetamol using physio/chemical methods, such as adsorption There is a wide range of adsorption materials used for paracetamol removal, this includes activated carbon (Cabrita et al., 2010; Ayyash et al., 2015).

Membrane separation technologies and adsorption are the most common methods in paracetamol removal from wastewater. Ayyash et al., (2015) investigated the performance of membrane systems for wastewater treatment and paracetamol removal. Another attempt was done by Nadour et. al. (2019) regarding the removal of different compounds including paracetamol using a carbonpolymeric membrane. Terzyk, A. P. (2002), have studied paracetamol adsorption at neutral pH. Cabrita (2010), studied the removal of analgesic compounds using activated carbons from urban residues. While Beninati (2008), studied the adsorption of Paracetamol using commercial activated carbons, Villaescusa (2011) studied the paracetamol removal by vegetable wastes. El-Rimawi, et al., (2018), studied the removal of Paracetamol as well as some selected pharmaceuticals micro-pollutants from aqueous solutions by using natural Jordanian Zeolite. While Velichkova (2017), studied heterogeneous Fenton oxidation for Paracetamol removal by the use of zeolite. Gypsum is mainly identified as a soft sulfate mineral that is composed of calcium sulfate Di-hydrate (Bello et al., 2013; Cornelis and Cornelius, 1985). Gypsum was applied successfully and extensively for the removal of dye (Rauf et al, 2009), pharmaceutical drugs and heavy metals (Igwegbe et al, 2019). Gypsum represents a more advantageous, cheap, and readily available adsorbent due to its abundance in nature and it not requiring pretreatment as an adsorbent (Rauf et al., 2009).

Received on September 23, 2019, accepted February 18, 2020. Correspondence concerning this article should be addressed to Hossam I. Al-Itawi (E-mail address: hosam v@ @otmail.com). ORCiD ID for Hossam Al-Itawi: https://orcid.org/0000-0003-1554-1793 
A multitude of researchers successfully used calcined gypsum in wastewater treatment. Igwegbe et al, (2019) utilized it for the removal of Phenol. Al-Rawajfeh et al, (2018) successfully used calcined gypsum in the removal of Ibuprofen, while Al-Itawi (2019) utilized it for the removal of Fluoride from artificial wastewater.

Paracetamol was previously found to be a retarder of crystallization of calcium sulfate hemihydrate (Plaster of Paris) (Alrawashdeh et al, 2014). This interaction with paracetamol takes place in the water when calcium and sulfate ions crystallize forming calcium dehydrates, where paracetamol in the solution will adsorb and ultimately incorporate in the crystallization process. The purpose of this work is to study the ability to use gypsum as a low-cost material for the removal of Paracetamol from wastewater. In addition to identifying the effects of mass of adsorbent (gypsum), contact time and solution temperature on the removal of Paracetamol under neutral $\mathrm{pH}$ conditions. Finally, the thermodynamics and kinetics of the adsorption process were investigated.

\section{Materials and Methods 1.1 Materials}

The gypsum was produced from Jabal Mulaih, in Tafila, Southern part of Jordan (Alrawashdeh, et al, 2014), and it was supplied by Rawabi for Mining Co., a local mining company located near Tafila Technical University, it mainly consists of calcium sulfate dihydrate $\left(\mathrm{CaSO}_{4} \cdot 2 \mathrm{H}_{2} \mathrm{O}\right)$, where it was crushed, milled and then calcined at $150-200^{\circ} \mathrm{C}$. Paracetamol (99\%) was obtained from $\mathrm{Al}-$ Hikmah Co., Amman, Jordan. Paracetamol stocks were prepared by dissolving $100 \mathrm{mg}$ of Paracetamol in $100 \mathrm{~mL}$ distilled water. This stock solution was then used in the preparation of synthetic wastewater samples with different concentrations.

\subsection{Adsorption Assays}

Batch sorption assays were conducted in a series of $500 \mathrm{~mL}$ glass beakers containing $250 \mathrm{~mL}$ of the Paracetamol solution. A predetermined amount of calcined gypsum depending on the assay was added to each one of the beakers. Experiments were conducted at an ambient temperature of $250 \mathrm{C}$, and the desired temperature, with a stirring time of 5-25 minutes. Experiments were conducted at neutral $\mathrm{pH}$ because earlier studies show that paracetamol favors adsorption in natural $\mathrm{pH}$ (Ferreira et al, 2015; Bernal et al, 2017) After the completion of each assay, samples were filtered. The filtrate of Paracetamol solutions was then subjected to UV-visible analysis to determine the remaining concentration (SPECTRACOMP602; Advanced Products, Milan, Italy). A calibration curve of absorbance against different concentrations of Paracetamol was constructed. The samples of Paracetamol solutions had been analyzed by UV before and after treatment to determine the amount of Paracetamol removed.

\subsection{Calculations}

\subsubsection{Paracetamol removal}

Batch Paracetamol removal was evaluated by accounting for its initial and final concentrations. Assuming that the only removal mechanism is through adsorption, Paracetamol removal is evaluated as:

Removal $(\%)=\frac{C_{o}-C_{e}}{C_{o}} \times 100$

where $C_{o}$ is the initial concentration of Paracetamol (mg/l) and $C_{e}$ is the equilibrium Paracetamol concentration (mg/l). Gypsum adsorbed Paracetamol is calculated by:

$Q_{e}=\frac{\left(C_{o}-C_{e}\right) V}{m}$

where $Q_{e}$ is the gypsum adsorbed Paracetamol concentration $(\mathrm{mg} / \mathrm{g}), \mathrm{V}$ the sample volume $(\mathrm{L})$, and $\mathrm{m}$ is the used gypsum mass $(\mathrm{g})$.

\subsubsection{Adsorption Thermodynamics}

The different thermodynamic parameters of the adsorption process will be evaluated through the effect of temperature on the thermodynamic equilibrium constant $(\mathrm{K})$, which is defined as follows:

$K=a_{s} / a_{e}=\left(v_{s} \times Q_{e}\right) /\left(v_{e} \times c_{e}\right)$

whereas is the activity of the adsorbed ion, ae is the activity of the in-solution ion at equilibrium, $v_{s}$ is the activity coefficient the adsorbed ion, and $v_{e}$ is the activity coefficient of the in-solution ion at equilibrium. The activity coefficients can be assumed to equal unity, as the in-solution ions concentration approaches zero. Eq. 3 can be simplified to:

$\lim \left(Q_{e \rightarrow 0}\right) \Rightarrow K=a_{s} / a_{e}=Q_{e} / c_{e}=c_{o}-c_{e} / c_{e}$ 
The change in standard free energy of adsorption $\left(\Delta G^{0}\right)$ is calculated by:

$\Delta G^{0}=-R \times T \times \ln (K)$

where $\mathrm{R}$ is the universal gas constant $\left(8.314 \times 10^{-3} \mathrm{~kJ} / \mathrm{K}\right)$ and $\mathrm{T}$ is the temperature $(\mathrm{K})$.

Change in Entropy $\left(\Delta S^{0}\right)$ and Enthalpy $\left(\Delta H^{0}\right)$ are evaluated through the Van't Hoff equation:

$\ln (K)=\Delta S^{0} / R-\Delta H^{0} / R T$

Values of $\Delta \mathrm{H}^{0}$ and $\Delta \mathrm{S} 0$ were obtained by fitting Equation 6 to values of $\ln (K)$ versus $1 / T$.

\subsubsection{Adsorption kinetics}

Adsorption kinetics describes the uptake rate of Paracetamol, which can describe the residence time of ions at the solid-liquid interface. The kinetics of adsorption depends mainly on: the sorbent surface area and the nature-concentration of the active sites responsible for the interaction with the targeted ions (Yuh-Shan, 2004). Additionally, Adsorption kinetic models are used to study the probable rate governing step. The kinetics of the adsorption of Paracetamol on gypsum was studied using the pseudo-secondorder, Elovich kinetic model, and Intra-particle diffusion model.

The pseudo-second-order kinetics can be represented as follows (Ho, 2006):

$t / Q(t)=1 / K_{2}+t / Q_{e}$

where $t$ is the contact time ( $\mathrm{min}), Q(t)$ is the adsorbed Paracetamol at time $\mathrm{t}(\mathrm{mg} / \mathrm{g}), K_{2}$ is the pseudo-second-order adsorption rate constant (g/mg.min). Values for the kinetic constant are evaluated by fitting dynamic adsorption data $(t / Q(t)$ vs. $t)$ to Eq. 7 .

The Elovich kinetic model is expressed as (Abdelkreem, 2013; Riahi et al, 2017):

$Q(t)=\ln (\alpha \beta) / \beta+\ln (t) / \beta$

where $\alpha$ is the initial adsorption rate $(\mathrm{mg} / \mathrm{g} \min )$ and $\beta$ is a parameter related to the extent of surface coverage and the activation energy for chemisorption $(\mathrm{g} / \mathrm{mg})$. Values for $\alpha$ and $\beta$ are evaluated by fitting dynamic adsorption data $(Q(t)$ vs. $t)$ to Eq. 8 .

The intra-particle diffusion equation can be written as (Reddy et al, 2012; Igwegbe et al, 2019):

$Q(t)=k_{P i} t^{1 / 2}+c_{i}$

where $C_{i}$ is a constant that provides an idea regarding the thickness of the boundary layer $(\mathrm{mg} / \mathrm{g})$ and $k_{P i}$ is the intra-particle diffusion rate constant (mg/g.min1/2). Values for ci and $k_{P i}$ are evaluated by fitting dynamic adsorption data $(Q(t)$ vs. $t)$ to Eq. 9.

\section{Results and Discussion}

\subsection{Effect of temperature on Paracetamol removal}

Figure 1 shows the Paracetamol removal percentage and the adsorbed amount by calcined gypsum at different operating temperatures. The influence of solution temperature on the removal of Paracetamol was investigated by varying the temperatures from 20 to $50^{\circ} \mathrm{C}$. As shown in Fig. 1, the adsorption of Paracetamol on gypsum increased slightly with increasing temperature, where it varied between $56.8 \%$ and $59.9 \%$ between 20 and $50^{\circ} \mathrm{C}$, respectively. Similarly, the amount of Paracetamol uptake by gypsum ranged between 34.1 and $35.9(\mathrm{mg} / \mathrm{g})$ between 20 and

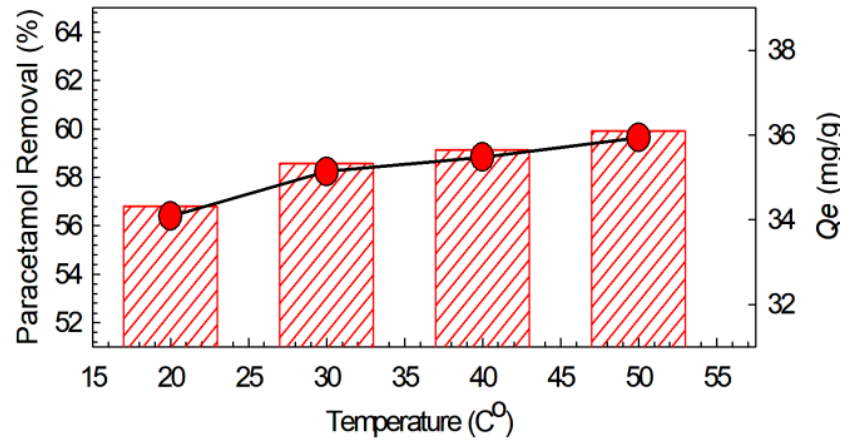

Fig .1 Paracetamol removal percentage and adsorbed amount at various temperatures after $5 \mathrm{~min}$ and with $1 \mathrm{gm}$ of gypsum. 
$50^{\circ} \mathrm{C}$, respectively. These results indicate that at the conditions of this experiment, the increased temperature did not have any effect on the amount of Paracetamol removed by gypsum.

\subsection{Effect of gypsum dose on Paracetamol removal}

Figure 2 shows the Paracetamol removal percentage and adsorbed amount by calcined gypsum at different initial doses. Mass of gypsum was increased from 0.5 to $3 \mathrm{~g}$, the percentage of Paracetamol removed on the adsorbent (gypsum) increased from $54.2 \%$ to $61.6 \%$. The increase in Paracetamol removal with increasing mass of gypsum is as a result of the increase in the number of adsorption sites and adsorbent surface area. The amount of Paracetamol per unit

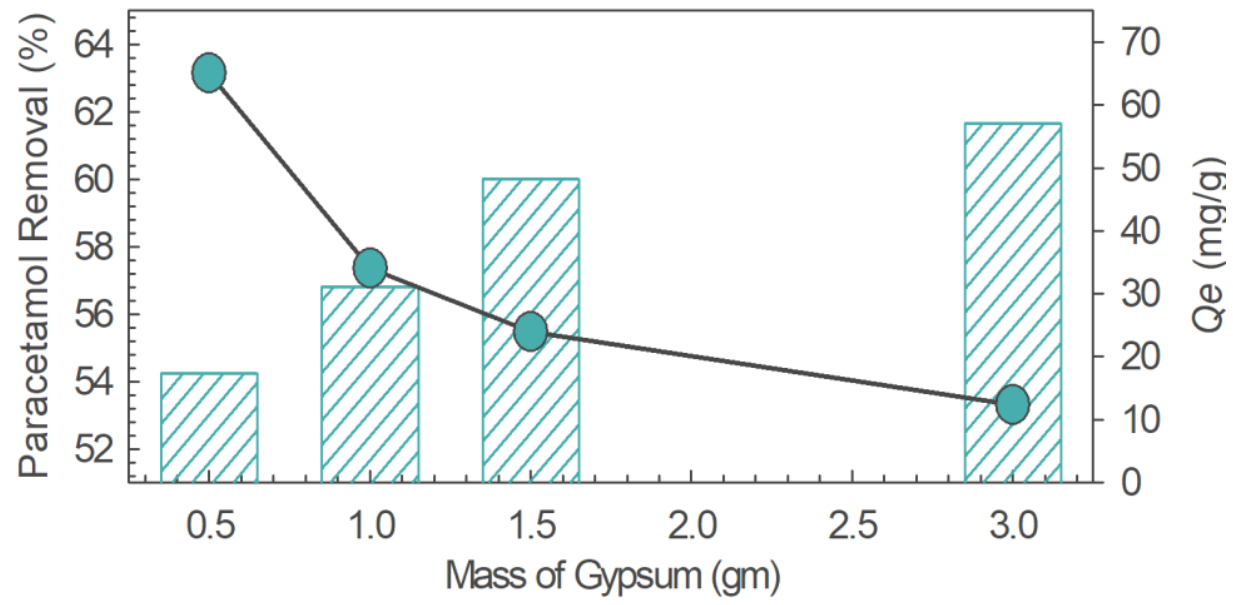
mass of the gypsum $\left(Q_{e}\right)$ decreased with increasing

Fig. 2 Paracetamol removal percentage at different initial gypsum dose after $5 \mathrm{~min}$ at $20^{\circ} \mathrm{C}$. adsorbent loading from 65.1 to 12.3 (mg/g). This is due to not fully using the adsorption cites at a higher adsorbent loading (Radnia et al, 2012; Gorzin and Abadi, 2018). A smaller dose of adsorbent will be saturated more quickly than a larger one (Meniai, 2012).

\subsection{Effect of contact time on Paracetamol removal}

Figure 3 shows Paracetamol removal percentage and adsorbed amount by calcined gypsum at different contact times with $1 \mathrm{gm}$ of gypsum at $20^{\circ} \mathrm{C}$. As seen in the figure, the maximum Paracetamol removal was obtained at the highest contact time studied (15 $\mathrm{min})$. The removal rate ranged varied between $56.8 \%$ and $65.3 \%$ between 5 and 15 min, respectively. This can be explained by the fact that the frequency of collision of the adsorbing material increasing with retention time, which increased the process of adsorption (Ahmadi and Igwegbe, 2018; Benosmane et al, 2018). Also, the adsorption sites were more available with time, resulting

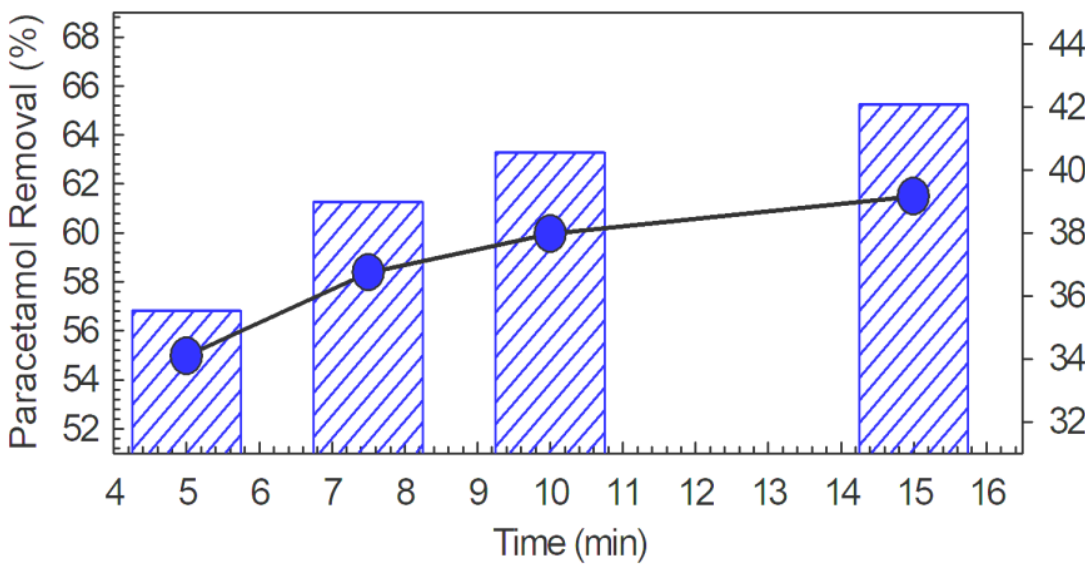

Fig. 3 Paracetamol removal percentage at different contact times with 1 gm of gypsum at $20^{\circ} \mathrm{C}$. in the amount of Paracetamol per unit mass of the gypsum $\left(Q_{e}\right)$ increasing from 34.8 to $39.2(\mathrm{mg} / \mathrm{g})$.

\subsection{Adsorption thermodynamics}

Table 1 shows the different thermodynamic parameters for the adsorption process, and Figure 4 shows the Van't Hoves plot for the system, and Figure 4 shows the Van't Hoff plot for the adsorption of Paracetamol on calcined gypsum. 
Table 1 Thermodynamic properties for the adsorption of Paracetamol on calcined gypsum

\begin{tabular}{ccccc}
\hline $\begin{array}{c}\text { Temperature } \\
\left({ }^{\circ} \mathrm{C}\right)\end{array}$ & $\mathrm{K}$ & $\Delta \mathrm{G}^{0}$ & $\Delta \mathrm{H}^{0}$ & $\Delta \mathrm{S}^{0}$ \\
$(\mathrm{~mol} / \mathrm{L})$ & $(\mathrm{J} / \mathrm{mol})$ & & \\
\hline 20 & 1.315 & -678.4 & & $13.3 \pm 1.8$ \\
30 & 1.414 & -857.9 & $3218.3 \pm 542.3$ & \\
40 & 1.447 & -915.9 & & \\
50 & 1.494 & -994.8 & & \\
\hline
\end{tabular}

As seen in Table 2, the negative value of $\Delta \mathrm{G}^{0}$ indicates the spontaneous nature of the adsorption of paracetamol on gypsum. However, values of $\Delta \mathrm{G}^{0}$ were found to be relatively small; less than $1 \mathrm{~kJ}$ and varied slightly at increasing temperatures. $\Delta \mathrm{G}^{0}$ for physical adsorption is between -20 and $0 \mathrm{~kJ} / \mathrm{mol}$ (Babakhouya et al, 2010; Atkins et al, 2018), implying that the adsorption of Paracetamol on gypsum is a physical adsorption process. Positive value of $\Delta H^{0}$ indicates the Paracetamol adsorption process is endothermic (Babakhouya et al, 2010; Adeogun and Balakrishnan, 2017), while the positive $\Delta S^{0}$ the value obtained indicate that the increase in the degree of disorderliness of the adsorbed species (AlOthman et al, 2014) and the affinity of the gypsum adsorbent for Paracetamol. This explains the lowered removal percentage calculated at higher temperatures. Moreover, due to a negative $\Delta \mathrm{S}_{0}$, the process of adsorption will increase disorder and randomness

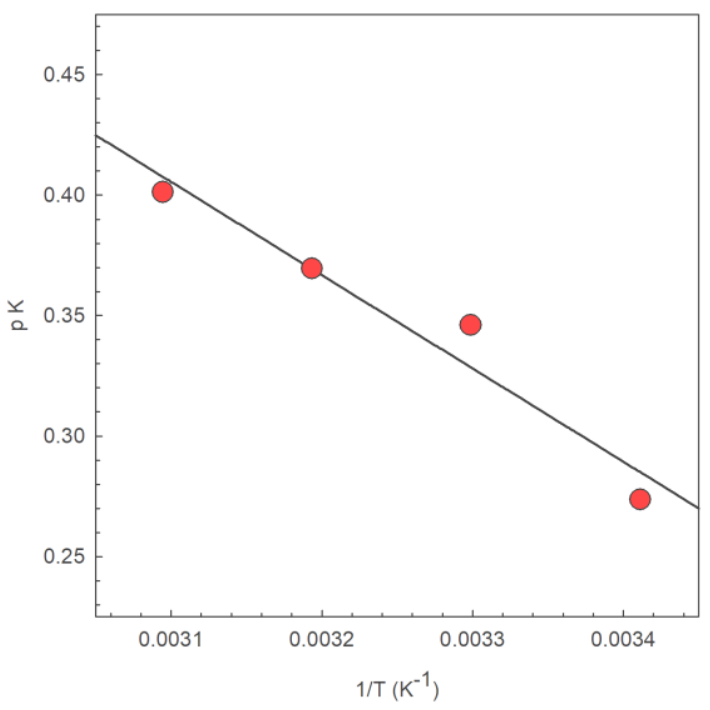

Fig 4. Van't Hoff plot for the adsorption of Paracetamol on calcined gypsum. Straight line represents Eq. 8 in the form: $k K=$ $\Delta S / 8.314-(\Delta H / T) / 8.314$ with an 2 value of 0.946 .

\subsection{Adsorption kinetics}

Table 3 shows the kinetic parameters for the pseudo-second-order and the Elovich kinetic model fitted to the dynamic adsorption data. Figures 5A and 5B show the kinetic Paracetamol adsorption data fitted to the pseudo-second-order kinetic model and the Elovich model

Table 3 Parameters for the pseudo-second-order and the Elovich kinetic models; values are presented as the best estimate \pm standard error.

\begin{tabular}{ccc}
\hline Model & Pseudo-Second order & Elovich \\
\hline Parameters & $\begin{array}{c}K_{2}=36.61 \pm 2.06(\mathrm{~g} / \mathrm{mg} \cdot \mathrm{min}) \\
Q e=42.22 \pm 0.27(\mathrm{mg} / \mathrm{g})\end{array}$ & $\begin{array}{c}\alpha=1666.3 \pm 167.6(\mathrm{mg} / \mathrm{g} \cdot \mathrm{min}) \\
\beta=0.218 \pm 0.031(\mathrm{~g} / \mathrm{mg})\end{array}$ \\
\hline$R^{2}$ & 0.9967 & 0.961 \\
\hline
\end{tabular}


Considering the values given in Table 2 for the regression coefficient, it is clear that with an $\mathrm{R}^{2}$ value of 0.9967 that the adsorption kinetic data obeys the pseudosecond-order model well. In contrast, the values of $\mathrm{R}^{2}$ for the Elovich model was 0.961 , indicating that the pseudo-secondorder model better represents the adsorption behavior. This behavior of calcined gypsum, when used as adsorbent, was reported by Igwegbe and colleagues (Igwegbe et al, 2019) in the adsorption of Phenol.
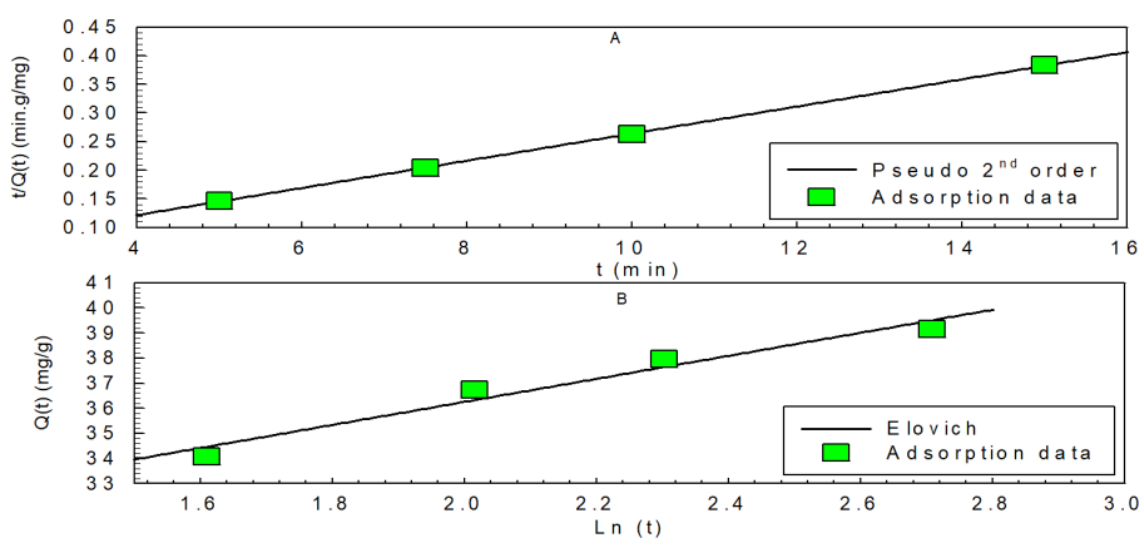

Fig 5. Kinetic Paracetamol adsorption data fitted to pseudo-second order kinetic model, and the Elovich model; lines represent the fitted model and points represent the data.

Table 4 Parameters for the Intra-Particle Diffusion kinetic model, as single and two stages; values are presented as best estimate \pm standard error

\begin{tabular}{|c|c|c|c|}
\hline Intra-particle Diffusion & Single Stage & \multicolumn{2}{|c|}{ Two Stages } \\
\hline Parameters & $\begin{array}{c}k_{P i}=3.01 \pm 0.62\left(\mathrm{mg} / \mathrm{g} \mathrm{min}{ }^{0.5}\right) \\
c_{i}=27.95 \pm 1.91(\mathrm{mg} / \mathrm{g})\end{array}$ & $\begin{array}{c}\text { Stage } 1 \\
k_{P i}=4.234 \pm 0.68\left(\mathrm{mg} / \mathrm{g} \mathrm{min}^{0.5}\right) \\
c_{i}=24.78 \pm 1.87(\mathrm{mg} / \mathrm{g})\end{array}$ & $\begin{array}{c}\text { Stage } 2 \\
k_{P i}=2.076 \pm 0.33\left(\mathrm{mg} / \mathrm{g} \mathrm{min}{ }^{0.5}\right) \\
c_{i}=31.18 \pm 1.08(\mathrm{mg} / \mathrm{g})\end{array}$ \\
\hline$R^{2}$ & 0.921 & 0.975 & 0.976 \\
\hline
\end{tabular}

For the Intra-Particle Diffusion Model Table 4 shows the kinetic parameters for the dynamic adsorption data fitted to the model as a single-stage and a two-stage process.

Figures 6A and 6B show the kinetic parameters for both scenarios. Fitting the data to a single-stage process resulted in a lower $\mathrm{R}^{2}$ value $(0.921)$ compared to a two-stage process (0.975 and 0.976). This indicates that indeed the removal of paracetamol by calcined gypsum is a two-stage process. The first stage in the intraparticle diffusion model can be attributed to instantaneous adsorption onto the outer surface, while the second stage represents gradual adsorption taking place where the adsorbate travels within the pores of the adsorbent (Hameed et al, 2008). As seen in Table 4, the initial instant adsorption stage had a higher $k_{P i}$ $(4.234 \pm 0.68$ vs. $2.076 \pm 0.33 \quad(\mathrm{mg} / \mathrm{g}$
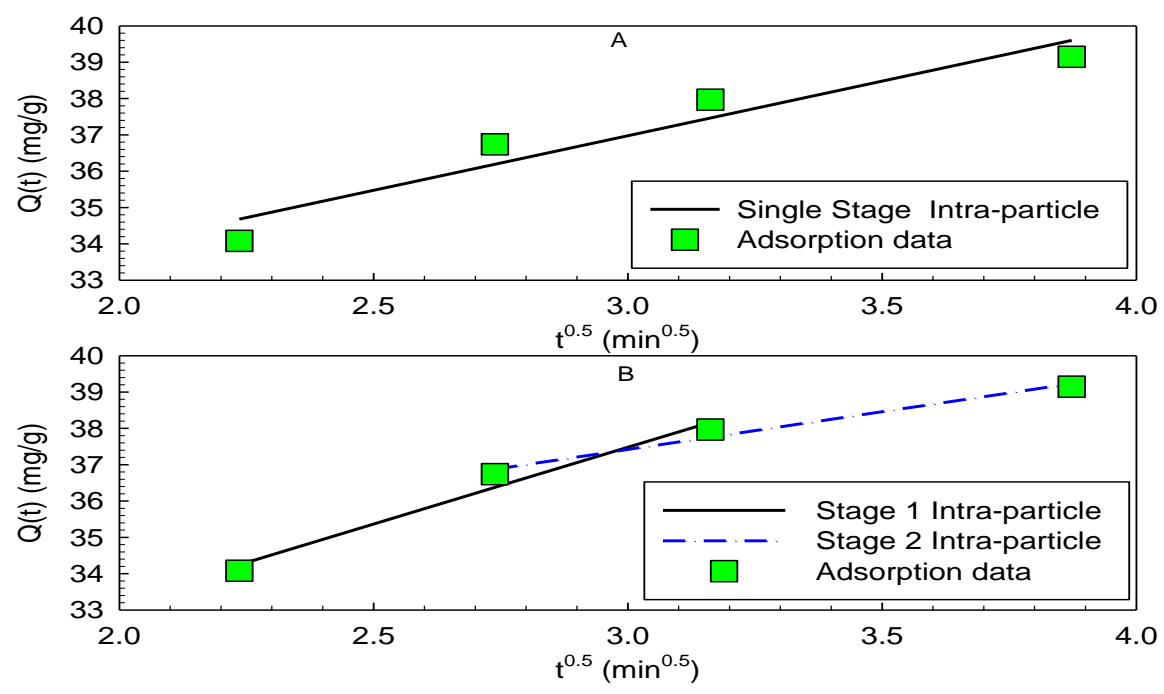

Fig. 6 Kinetic Paracetamol adsorption data fitted to the Intra-Particle Diffusion model as a single and two stages; lines represent the fitted model and points represent the data $\left.\left.\min ^{0.5}\right)\right)$, and a lower $c_{i}(24.78 \pm 1.87$ vs.

$31.18 \pm 1.08(\mathrm{mg} / \mathrm{g}))$, indicating a faster rate and a smaller thickness of the boundary layer in the first stage.

One final observation could be made after examining Figure 6, in the intra-particle diffusion model plot, the line between the data points did not pass through the origin point, which may indicate that the intra-particle diffusion is not the only rate-limiting step in paracetamol adsorption (Ma et al, 2013). This additional step can be attributed to nature by which paracetamol interacts with calcined gypsum (i.e. inclusion in the re-crystallization process) (Alrawashdeh et al, 2014). 


\section{Conclusions}

The potential and ability of calcined gypsum in removing paracetamol from aqueous solutions were investigated. Effects of calcined gypsum mass, contact time and solution temperature on the adsorption process were studied. Calcined gypsum was found to be able to remove paracetamol, via adsorption, from aqueous solutions at neutral $\mathrm{pH}$ conditions. The increased temperature had a minor effect on the removal of paracetamol while increasing the initial calcined gypsum dose and contact time increased the removal of paracetamol.

The adsorption process was found to be spontaneous and endothermic, evident by the thermodynamic parameters, and more likely is a physical adsorption process. Kinetically, the adsorption of paracetamol by calcined gypsum was found to be best represented by the Pseudo-Second order model, followed by the Elovich kinetic model. Finally, the Intra-particle diffusion model analysis indicated that the removal process mainly consists of two stages. Also, it could be deduced from the kinetic behavior of paracetamol adsorption that the recrystallization process can be another rate-limiting step in the process.

\section{Nomenclature}

\section{Symbols}

$\begin{array}{lll}C_{0} & =\text { Initial concentration of paracetamol } & {[\mathrm{mg} / \mathrm{l}]} \\ C_{e} & =\text { Equilibrium concentration of paracetamol } & {[\mathrm{mg} / \mathrm{l}]} \\ C_{i} & =\text { Constant in the intra-particle diffusion equation model } & {[\mathrm{mg} / \mathrm{g}]} \\ t & =\text { Time } & {[\mathrm{min}]} \\ Q_{e} & =\text { Gypsum adsorbed concentration of paracetamol } & {[\mathrm{mg} / \mathrm{g}]} \\ Q_{(t)} & =\text { Gypsum adsorbed concentration of paracetamol at time t } & {[\mathrm{mg} / \mathrm{g}]} \\ V & =\text { Sample volume } & {[1]} \\ m & =\text { Gypsum mass } & {[\mathrm{g}]} \\ K & =\text { Thermodynamic equilibrium constant } & {[\mathrm{mo} / \mathrm{l}]} \\ K_{2} & =\text { Pseudo second order adsorption rate } & {[\mathrm{g} / \mathrm{mg} . \mathrm{min}]} \\ k_{p i} & =\text { Rate constant in the intra-particle diffusion equation model } & {[\mathrm{g} / \mathrm{mg} \cdot \mathrm{min} 1 / 2]} \\ a_{s} & =\text { activity of the adsorbed ion } & {[-]} \\ a_{e} & =\text { activity of the in-solution ion at equilibrium } & {[-]} \\ v_{s} & =\text { activity coefficient of the adsorbed ion } & {[-]} \\ v_{e} & =\text { activity coefficient of the in-solution ion at equilibrium } & {[-]} \\ \mathrm{R} & =\text { The universal gas constant } & {[\mathrm{kJ} / \mathrm{K}]} \\ \mathrm{T} & =\text { The temperature } & {[\mathrm{K}]} \\ \Delta \mathrm{G}_{0} & =\text { Change in standard free energy } & {[\mathrm{J} / \mathrm{mol}]} \\ \Delta \mathrm{H}_{0} & =\text { Change in enthalpy } & {[\mathrm{J} / \mathrm{mol}]} \\ \Delta \mathrm{S}_{0} & =\text { Change in ntropy } & {[\mathrm{J} / \mathrm{mol} . \mathrm{K}]} \\ \mathbf{G r e e k} & \text { letters } & \\ \alpha & =\text { First parameter in the Elovich kinetic mode } & {[\mathrm{mg} / \mathrm{g} \cdot \mathrm{min}]} \\ \beta & =\text { Second parameter in the Elovich kinetic mode } & {[\mathrm{g} / \mathrm{mg}]}\end{array}$

\section{References}

Abdelkreem, M. "Adsorption of phenol from industrial wastewater using olive mill waste", APCBEE procedia, 5, 349-357.(2013).

Adeogun, A., and Balakrishnan, R. "Kinetics, isothermal and thermodynamics studies of electrocoagulation removal of basic dye rhodamine b from aqueous solution using steel electrodes", Appl. Water Sci., 7, 1711-1723 (2017).

Ahmadi, S. and Igwegbe, C. "Adsorptive removal of phenol and aniline by modified bentonite: Adsorption isotherm and kinetics study", Appl. Water Sci. 8, 4-8 (2018).

Al-Itawi, H. "Removal of Fluoride from Wastewater by Calcined Gypsum: Adsorption and Kinetics Study." J. of Eng. Sci. and Tech., 14,1301-1313 (2019) Al-Rawajfeh, A., Al-Saqarat, B., Al-Ma'abreh, A., Al-Itawi, H., Alrawashdeh, A., AlShamaileh, E., and Sillanpaa, M." Utilization of Calcined Gypsum in Water and Wastewater Treatment: Removal of Ibuprofen". Jordanian J. of Eng. and Chem. Indust. (JJECI), 1, 78-83 (2018)

Alrawashdeh, A., Al-Rawajfeh, A., Al-Bedoor, A., Al-Shamaileh, E., and Al-Hanaktah, M. "Production of plaster from gypsum deposits in south jordan: improvement of the setting time". J. of Chem.l Tech. and Metallur. 49, 293-302 (2014)

Atkins, P., De Paula, J. and Keeler, J.; "Atkins' physical chemistry", Oxford university press, (2018).

Ayyash, F., Kamis, M., Khalaf, S., Thawabteh, A. and Karaman, R. "Removal of aspirin, salicylic acid, paracetamol and p-aminophenol by advanced membrane technology activated charcoal and clay micelles complex", Case Studies J., 4, 74-110 (2015).

Babakhouya, N., Boughrara, S. and Abad, F. "Kinetics and thermodynamics of cd (ii) ions sorption on mixed sorbents prepared from olive stone and date pit from aqueous solution", Amer. J. of Env. Sci., 6, 470-476 (2010).

Bernal, V., Erto, A., Giraldo, L., and Moreno-Piraján, J. "Effect of solution pH on the adsorption of paracetamol on chemically modified activated carbons". Molecules, 22, 1-14 (2017).

Beninati, S., Semeraro, D. and Mastragostino, M. "Adsorption of paracetamol and acetylsalicylic acid onto commercial activated carbons", Adsorp. Sci.and Tech., 26, 721-734 (2008). 
Benosmane, N., Boutemeur, B., Hamdi, S., and Hamdi, M. "Removal of phenol from aqueous solution using polymer inclusion membrane based on mixture of CTAa and CA", Appl. Water Sci., 8, 2-6 (2018).

Bello, O, Bello, L., Adegoke, K. "Adsorption of dyes using different types of sand: a review", S Afr J Chem., 66, 117-129 (2013).

Cabrita, I., Ruiz, B., Mestre, A., Fonseca, I., Carvalho, A., and Ania, C. "Removal of an analgesic using activated carbons prepared from urban and industrial residues", Chem. Eng. J., 163, 249-255 (2010).

Cornelis, K., and Cornelius, S. "Manual of Mineralogy", 20 $0^{\text {th }}$ Edn., John Wiley, 352-353. (1985)

Felis, E. and Miksch, K. "Removal of analgesic drugs from the aquatic environment using photochemical methods", Water Sci. and Tech., 60, 2253-2259 (2009).

El-Rimawi, F., Daana, M., Khamis, M., Karaman, R., Khoury, H. and Qurie, M. "Removal of selected pharmaceuticals from aqueous solutions using natural Jordanian zeolite", Arab. J. for Sci. and Eng., 44, 209-215 (2019).

Ferreira, R., Couto Junior, O., Carvalho, K., Arroyo, P., and Barros, M. " Effect of solution $\mathrm{pH}$ on the removal of paracetamol by activated carbon of dende coconut mesocarp". Chem. and Bioch. Eng. quart., 29, 47-53 (2015)

Gorzin, F. and Bahri, A., "Adsorption of cr (vi) from aqueous solution by adsorbent prepared from paper mill sludge: Kinetics and thermodynamics studies", Adsorp. Sci. and Tech., 36, 149-169 (2018).

Hameed, B., Tan, I., and Ahmad, A. "Adsorption isotherm, kinetic modeling and mechanism of 2, 4, 6-trichlorophenol on coconut husk-based activated carbon". Chem. Eng. J., 144, 235-244 (2008).

Ho, Y. "Second-order kinetic model for the sorption of cadmium onto tree fern: A comparison of linear and non-linear methods", Water Res., 40, 119-125 (2006).

Igwegbe, C., Al-Rawajfeh A., Al-Itawi, H., Sharadqah, S., Al-Qazaqi, S., Abu Hashish, E., Al-Qatatsheh, M, and Sillanpaa, M., "Utilization of Calcined Gypsum in Water and Wastewater Treatment: Removal of Phenol." J. of Ecol. Eng., 20, 1-10 (2019).

Karaman, R., Khamis, M., Abbadi, J., Amro, A., Qurie, M., Ayyad, I., Ayyash, F., Hamarsheh, O., Yaqmour, R. and Nir, S. "Paracetamol biodegradation by activated sludge and photocatalysis and its removal by a micelle-clay complex, activated charcoal, and reverse osmosis membranes", Env. Tech., 37, 2414-2427 (2016).

Kong, W., Wang, B., Ma, H. and Gu, L. "Electrochemical treatment of anionic surfactants in synthetic wastewater with three-dimensional electrodes", Journal of Hazardous Materials, 137, 1532-1537.(2006).

Ma, Y., Gao, N., Chu, W. and Li, C. "Removal of phenol by powdered activated carbon adsorption", Frontiers of Env. Sci. and Eng., 7, 158-165.(2013).

Meniai, A. "The use of sawdust as by product adsorbent of organic pollutant from wastewater: Adsorption of phenol", Energy Procedia, 18, 905-914.(2012).

Nadour, M., Boukraa, F. and Benaboura, A. "Removal of diclofenac, paracetamol and metronidazole using a carbon-polymeric membrane", Journal of Env. Chem. Eng., 7, 1-12, (2019).

Radnia, H., Ghoreyshi, A., Younesi, H. and Najafpour, G. "Adsorption of Fe (ii) ions from aqueous phase by chitosan adsorbent: Equilibrium, kinetic, and thermodynamic studies", Desal. and Water Treat., 50, 348-359.(2012).

Ratpukdi, T. "Degradation of paracetamol and norfloxacin in aqueous solution using vacuum ultraviolet (vuv) process", J. of Clean Energy Tech., 2, 168170 (2014).

Rauf, M., Shehadeh, L., Ahmed, A., and Al-Zamly, A. "Removal of methylene blue from aqueous solution by using gypsum as a low cost adsorbent" World Academy of Sci., Eng. and Tech., 3, 540-545 (2009)

Reddy, M., Sivaramakrishna, L., and Reddy, A. "The use of an agricultural waste material, Jujuba seeds for the removal of anionic dye (congo red) from aqueous medium", J. of Haz. Mat., 203, 118-127 (2012).

Riahi, K., Chaabane, S., and Thayer, B. "A kinetic modeling study of phosphate adsorption onto phoenix dactylifera 1. Date palm fibers in batch mode", $J$. of Saudi Chem. Soci., 21, S143-S152 (2017).

Terzyk, A. "Adsorption of biologically active compounds from aqueous solutions on to commercial unmodified activated carbons. Part iii. Theoretical description of paracetamol adsorption data at neutral pH", Adsor. Sci. and Tech., 20, 63-81 (2002).

Velichkova, F., Delmas, H., Julcour, C. and Koumanova, B. "Heterogeneous fenton and photo-fenton oxidation for paracetamol removal using iron containing zsm-5 zeolite as catalyst", AIChE J., 63, 669-679 (2017).

Villaescusa, I., Fiol, N., Poch, J., Bianchi, A. and Bazzicalupi, C. "Mechanism of paracetamol removal by vegetable wastes: The contribution of $\pi-\pi$ interactions, hydrogen bonding and hydrophobic effect", Desalination, 270, 135-142 (2011).

Yuh-Shan, H. "Citation review of lagergren kinetic rate equation on adsorption reactions", Scientometrics, 59, 171-177 (2004). 